\title{
Evolution from microscopic transoral to endoscopic endonasal odontoidectomy
}

\author{
*Juan Antonio Ponce-Gómez, M.D., ${ }^{1}$ Luis Alberto Ortega-Porcayo, M.D., ${ }^{1}$ \\ Hector Enrique Soriano-Barón, M.D., ${ }^{2}$ Arturo Sotomayor-González, M.D., 1 \\ Nicasio Arriada-Mendicoa, M.D., ${ }^{1}$ Juan Luis Gómez-Amador, M.D., ${ }^{1}$ \\ Marité Palma-Díaz, M.D., ${ }^{3}$ and Juan Barges-Coll, M.D., M.Sc. ${ }^{1}$ \\ Departments of ' Neurological Surgery and ${ }^{3}$ Otoneurology, National Institute of Neurology and Neurosurgery \\ “Manuel Velasco Suarez," Mexico City, Mexico; and ${ }^{2}$ Spine Lab Biomechanics, Barrow Neurological \\ Institute, Phoenix, Arizona
}

\begin{abstract}
Object. The goal of this study was to compare the indications, benefits, and complications between the endoscopic endonasal approach (EEA) and the microscopic transoral approach to perform an odontoidectomy. Transoral approaches have been standard for odontoidectomy procedures; however, the potential benefits of the EEA might be demonstrated to be a more innocuous technique. The authors present their experience with 12 consecutive cases that required odontoidectomy and posterior instrumentation.

Methods. Twelve consecutive cases of craniovertebral junction instability with or without basilar invagination were diagnosed at the National Institute of Neurology and Neurosurgery in Mexico City, Mexico, between January 2009 and January 2013. The EEA was used for 5 cases in which the odontoid process was above the nasopalatine line, and was compared with 7 cases in which the odontoid process was beneath the nasopalatine line; these were treated using the transoral microscopic approach (TMA). Odontoidectomy was performed after occipital-cervical or cervical posterior augmentation with lateral mass and translaminar screws. One case was previously fused (Oc-C4 fusion). The senior author performed all surgeries. American Spinal Injury Association scores were documented before surgical treatment and after at least 6 months of follow-up.

Results. Neurological improvement after odontoidectomy was similar for both groups. From the transoral group, 2 patients had postoperative dysphonia, 1 patient presented with dysphagia, and 1 patient had intraoperative CSF leakage. The endoscopic procedure required longer surgical time, less time to extubation and oral feeding, a shorter hospital stay, and no complications in this series.

Conclusions. Endoscopic endonasal odontoidectomy is a feasible, safe, and well-tolerated procedure. In this small series there was no difference in the outcome between the EEA and the TMA; however, fewer complications were documented with the endonasal technique.

(http://thejns.org/doi/abs/10.3171/2014.7.FOCUS14301)
\end{abstract}

KEY WORDS • craniovertebral junction • endoscopic endonasal approach
transoral microscopic approach $\bullet \quad$ odontoidectomy

$\mathrm{S}$ EVERAL surgical routes have been described for the craniovertebral junction $(\mathrm{CVJ})$ region because of its unique anatomy and vital surrounding structures. The transoral approach with microscopic assistance has been the standard procedure to perform an odontoidectomy, in accordance with the etiology of the disease, the

\footnotetext{
Abbreviations used in this paper: $\mathrm{AAS}=$ atlantoaxial subluxation; ASIA = American Spinal Injury Association; BI = basilar invagination; $\mathrm{CTA}=\mathrm{CT}$ angiography; $\mathrm{CVJ}=$ craniovertebral junction; $\mathrm{EEA}$ $=$ endoscopic endonasal approach; $\mathrm{EEO}=$ endoscopic endonasal odontoidectomy; TMA = transoral microscopic approach; $\mathrm{TMO}=$ transoral microscopic odontoidectomy; VPI = velopharyngeal insufficiency.

* Drs. Ponce-Gómez and Ortega-Porcayo contributed equally to this work.
}

mechanism of compression, and whether the bone could or could not be reduced..$^{19,21}$ Odontoidectomy is necessary when there is a nonreducible bony compression ${ }^{20}$ of the spinal cord or soft-tissue pannus, causing severe ventral compression and resulting in progressive myelopathy. ${ }^{6}$ Without cord contusion or progressive myelopathy, posterior decompression and fusion will lead to reduction over time..$^{23}$

The risk of bacterial contamination, prolonged postoperative intubation, nasogastric tube feeding, tongue swelling, and nasopharyngeal incompetence after transoral surgery ${ }^{5}$ have led researchers to identify alternative routes to reach this region. The possibility of performing an odontoidectomy through the nose is strictly related to how high the $\mathrm{Cl}-2$ junction is in relation to 


\section{J. A. Ponce-Gómez et al.}

the nasal bones and the hard palate. Cadaveric studies have demonstrated its feasibility. ${ }^{1,22}$ In 2005, Kassam et al. ${ }^{14}$ documented an expanded endoscopic endonasal approach (EEA), which has since been used, modified, and reported by several authors. . $^{911,12,16-18,34,36}$

We present our experience with craniocervical pathological entities that required posterior instrumentation and odontoidectomy. Endoscopic endonasal odontoidectomy (EEO) and transoral microscopic odontoidectomy (TMO) are described, analyzed, and compared.

\section{Methods}

Our senior author (J.B.C.) performed all the surgeries at the National Institute of Neurology and Neurosurgery in Mexico City between January 2009 and January 2013. All of the patients provided a medical history. A thin-cut CT angiography (CTA) study of the cervical spine was taken, providing a detailed evaluation of the vascular and bony structures of the atlas and axis. Magnetic resonance imaging was used to evaluate neural compression, and CTA and MRI were used for neuronavigation. Patient information including demographic data, clinical outcome, surgical approach, operative details, reconstruction, and complications were collected.

Twenty-seven cases of CVJ instability were documented between 2009 and 2013. Fifteen patients required posterior instrumentation; 12 of the cases required odontoidectomy and posterior instrumentation and were included in this study. Seven surgeries were performed using a transoral microscopic approach (TMA) and 5 using EEA. The basilar invagination (BI) was measured using the Chamberlain line (values $\geq 6 \mathrm{~mm}$ were considered positive). Atlantoaxial subluxation (AAS) was diagnosed using the anterior atlantodental interval (values $>5 \mathrm{~mm}$ were considered positive) and the posterior atlantodental interval (values $<14 \mathrm{~mm}$ were considered positive).

We performed descriptive statistics analysis with IBM SPSS Statistics software version 19.0. The continuous variables were compared using the Mann-Whitney Utest or t-test, according to the distribution after performing the normality tests (Kolmogorov and Shapiro-Wilk test). The categorical variables were compared using the Pearson chi-square test, the Fisher exact test, or the Kruskal-Wallis test, depending on the variables. The statistical significance was set at $\mathrm{p} \leq 0.05$.

\section{Surgical Techniques}

The EEA was used in the cases in which the odontoid process was above the nasopalatine line, ${ }^{7}$ a straight line starting from the inferior midpoint of the nasal bone and ending at the lowest point on the odontoid or C-2 while remaining tangential to, but not crossing, the hard palate $^{2}$ (Fig. 1D). The TMA was used when the dens was below the nasopalatine line. All of the cases were performed using the neuronavigation system (VectorVision 2, Brainlab), C-arm fluoroscope, and with the aid of electrophysiological monitoring in which the somatosensory evoked potentials were used. Patients were intubated by a neuroanesthesiologist using an armored oral endotracheal tube. Ten minutes before surgery was started, $1 \mathrm{~g}$ of ceftriaxone and $600 \mathrm{mg}$ of clindamycin were administered. The patient was positioned supine, with the head fixed to a Mayfield head holder; the central face area was prepared and draped in sterile fashion.

\section{Endoscopic Endonasal Odontoidectomy}

We use a Karl Storz $0^{\circ} 18 \mathrm{~cm} \times 4 \mathrm{~mm}$ endoscope attached to a high-definition camera with an irrigating sheath. The head is placed with a slight flexion and tilted toward the surgeon. The nostrils of the patient faced right-handed operators. Endoscopic and navigation monitors are placed cephalic to the patient. We use a binostril approach. No endoscopic holder was used; an assistant holds the camera and irrigates when needed. Partial sphenoidectomy is done and the posterior septum is detached from the vomer. The midline mucosa and fascia are incised along the raphe using monopolar electrocautery. The longus capitis and longus colli muscles are reflected laterally. The carotid canals, pterygoid canal, and vidian nerve are identified with navigation assistance, and then the fossa of Rosenmüller is visualized.

Neuronavigation is important for localizing the lower clivus and anterior arch of $\mathrm{C}-1$. We began exposing the anterior arch of C-1 and the lower clivus depending on the $\mathrm{BI}$, when preservation of the anterior arch of the atlas was done if feasible. The arch of C-1 was displaced with a dissector, the odontoid was drilled out with an angulated high-speed drill until a very thin layer of bone was left, and then the Kerrison rongeur was used to take the thin layer of bone. In some cases of BI we had to drill out the most inferior part of the clivus and the arch of C-1 to get to the tip of the odontoid. The extent of the resection was confirmed with neuronavigation and fluoroscopy. The surgical defect was covered with Gelfoam and fibrin glue (Video 1).

VIDEo 1. Video showing the EEA. Copyright Juan BargesColl. Published with permission. Click here to view with Media Player. Click here to view with Quicktime.

\section{Transoral Microscopic Odontoidectomy}

The patients are positioned supine with the head in extension. Two retractors are placed to move the tongue and the endotracheal tube away. The midline is identified using neuronavigation; mucosa and muscles are incised along the raphe using monopolar electrocautery. We start drilling the anterior arch of $\mathrm{C}-1$ or the lower clivus to expose the odontoid process, and when feasible preservation of the anterior arch is done. The next step is to detach the apical ligaments of the dens with an angle curette and Kerrison rongeurs. Finally, we drill out the dens with a 6 - $\mathrm{mm}$ ball diamond tool. When the soft tissue (pannus) is encountered, we remove it partially until the dura mater is visualized and preserved. Fluoroscopy and neuronavigation are used to confirm the extent of the decompression. At the end of the operation a nasogastric tube is placed (Video 2).

VIDEo 2. Video showing the TMA. Copyright Juan BargesColl. Published with permission. Click here to view with Media Player. Click here to view with Quicktime. 

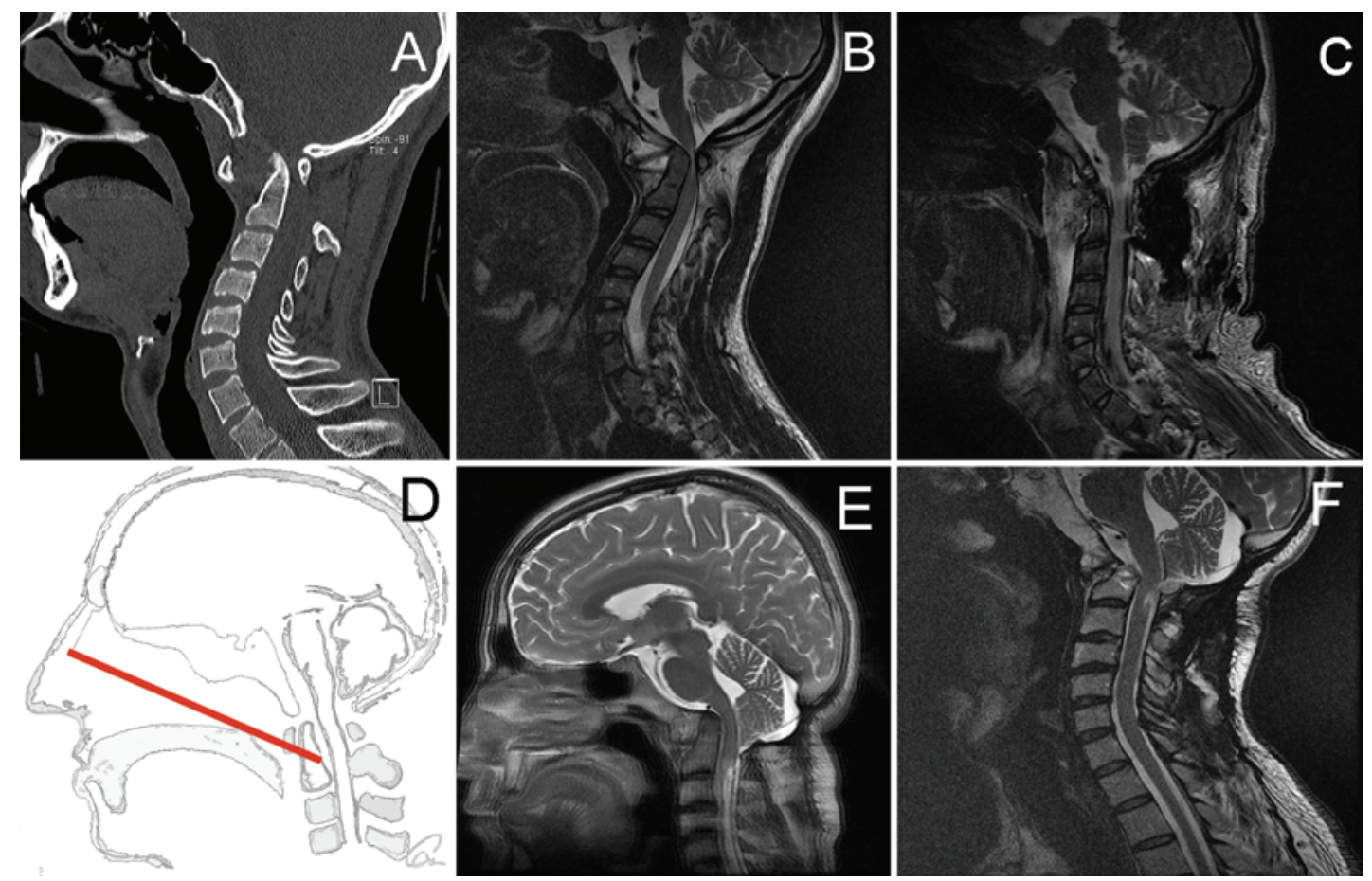

FIG. 1. A-C: Case 7 (TMO group). Preoperative sagittal CT scan (A) and MRI study (B) obtained in a patient with AAS. Postoperative sagittal MRI study (C) obtained after 6 months showing adequate decompression with persistent signs of myelopathy. D-F: Case 3 (EEO group). Schematic representation (D) of the nasopalatine line, which helps to decide if an EEA is feasible. Preoperative sagittal MRI study (E) of a patient with Chiari malformation and AAS. Postoperative sagittal MRI study $(F)$ obtained after 6 months showing adequate decompression with resolution of the Chiari malformation and syrinx improvement.

\section{Results}

Twenty-seven cases of CVJ instability were documented between 2009 and 2013. Fifteen patients required posterior instrumentation; only 12 of the cases required odontoidectomy and posterior instrumentation and were included in this study. One already had occipital-cervical instrumentation and required an odontoidectomy. An EEA was performed in 5 cases and a TMA in 7 cases. Complete odontoid resection with adequate anterior decompression and fixation was successfully obtained in all patients (Figs. 1 and 2). Adequate anterior decompression was achieved when CSF was observed anterior to the cervical medulla or brainstem in the MRI studies.

The demographic data of the patients are shown in Table 1. Basilar invagination was demonstrated using the Chamberlain line (mean $11 \mathrm{~mm}$ ) in 4 cases from the EEO group and in 2 cases from the TMO group (mean $6 \mathrm{~mm}$ ).

The most common diagnosis was AAS, which was associated with rheumatoid arthritis in 4 cases and Chiari malformation in 2 cases. Odontoidectomy with anterior arch preservation was performed in 7 cases with both techniques. When the preservation of the anterior arch was thought to be not feasible after the CTA and MRI analyses, we performed an Oc-C2 fixation technique (Table 2). Seven cases were fixated using lateral mass and translaminar screws $(\mathrm{C} 1-2)$ via a posterior approach in the same surgical time (Fig. 2), before the odontoidectomy was performed. Four cases were fixated with occipital-cervical instrumentation $(\mathrm{Oc}-\mathrm{C} 2)$. One case had undergone a previous fixation $(\mathrm{Oc}-\mathrm{C} 4)$ in another hospital.
The endoscopic approach required a longer surgical time (EEO 238 minutes vs TMO 141 minutes) $(\mathrm{p} \leq 0.02)$, involved more bleeding (EEO $572 \mathrm{ml}$ vs TMO $91 \mathrm{ml})(\mathrm{p}$ $\leq 0.01$ ), and fewer postoperative stay days (EEO 2.8 days vs TMO 6.5 days) $(\mathrm{p} \leq 0.01)$. All patients from the EEO group were extubated postoperatively and started on fluids 12 hours after surgery. In the TMO group, 6 patients remained intubated for 24 hours and 1 for 48 hours; oral feeding started with fluids 72 hours after surgery. Time to extubation and oral feeding was significantly shorter in the EEA group ( $p \leq 0.001$ vs $p \leq 0.009$ ). We had no complications in the endoscopic group. Two patients from the TMA group presented with postoperative dysphonia, 1 patient experienced dysphagia, and 1 patient had a minor CSF leak that was repaired intraoperatively with a fat graft and a fibrin sealant. The dysphonia and dysphagia resolved 2 weeks after the surgery.

In regard to outcome, 9 patients had recovery of neurological function according to evaluation with the American Spinal Injury Association (ASIA) scale at least 6 months after surgery, with improvement of motor function and reduction of neck pain. Three patients had reduction of neck pain without motor function improvement (Table 1).

\section{Discussion}

The transoral corridor is the mainstay route used for CVJ pathological entities because it is safe, fast, and efficacious. ${ }^{19}$ The EEA works as an alternative for CVJ lesions located above the level of the atlas rim, and based on our experience, it could be considered as the standard 

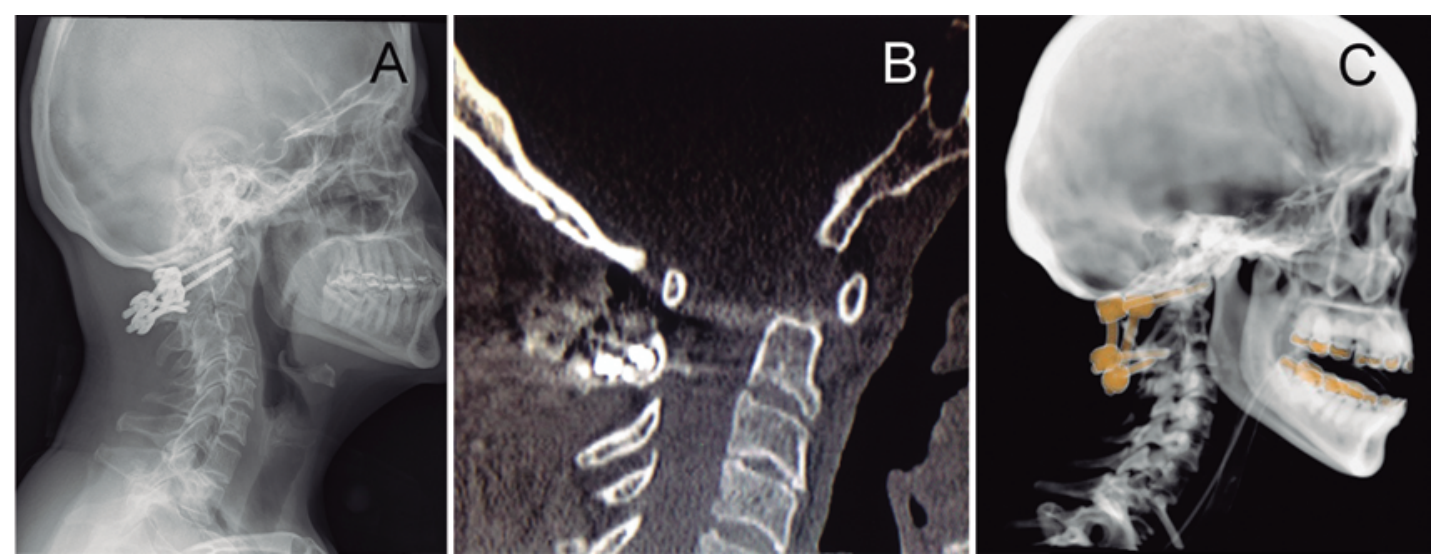

FIG. 2. Postoperative lateral radiographs (A and $\mathrm{C}$ ) and $\mathrm{CT}$ scan $(\mathrm{B})$ showing $\mathrm{C}-1$ lateral mass screws and $\mathrm{C}-2$ translaminar screws. Notice the preservation of the anterior arch of $\mathrm{C}-1$ (B).

procedure in cases with BI. Very high BI can become problematic with the transoral approach; visualization of the tip of the odontoid becomes difficult and the endonasal approach may be more direct.

The major risk when treating the anterior portion of the CVJ is the vertebral artery, which is $24 \mathrm{~mm}$ lateral to $\mathrm{C}-1$, as stated by Crockard. ${ }^{5}$ The only visual obstruction is the venous bleeding during the inferior third clivectomy, which is easily controlled using fibrin sealant. The visual anatomy of the CVJ via endonasal and transoral approaches is similar, with a different angle of attack; the direction to reach the odontoid is straight ahead using the EEA and angled upward with the transoral approach. ${ }^{29}$ There is a shorter distance to the surgical target when using EEA, as demonstrated by Baird et al., ${ }^{2}$ and the views between the endoscope and microscope are different; we believe that the movements in such a small working area are more fluent and faster with an endoscope. Drilling is more comfortable because the surgeon holds the drill closely with the desired angle, without obstructing the view and with better illumination.

The advantages of EEA are a smaller incision in the nasopharynx, which is in theory less contaminated than the more caudal transoral route. ${ }^{7,14,34}$ With EEA, a middle turbinectomy or removal of the posterior portion of the nasal septum could enlarge the surgical corridor without causing postoperative respiratory problems. Mouth retractors are not necessary and prolonged compression of the tongue or split of the soft palate are avoided. Unlike the transoral approaches, ${ }^{5}$ there is no need for a nasogastric tube postoperatively, and the risk of upper airway swelling is minor.

Serious complications documented in previous case reports and clinical series ${ }^{3,9-12,14,16,17,25,26,30,31,34}$ are infrequent. However, maintaining the integrity of the dura mater is crucial. Magrini et al. ${ }^{18}$ reported a CSF leak repaired with a fat graft and replacing the mucosal flap; Wu et al. ${ }^{34}$ repaired 1 of their 3 cases with fat graft and fibrin glue.

TABLE 1: Diagnosis, management, and outcome in 12 patients with odontoidectomy*

\begin{tabular}{|c|c|c|c|c|c|c|c|c|c|}
\hline \multirow[b]{2}{*}{ Case No. } & \multirow[b]{2}{*}{ Diagnosis } & \multirow{2}{*}{$\begin{array}{c}\text { Age (yrs) } \\
\text { Sex }\end{array}$} & \multirow[b]{2}{*}{$\mathrm{BI}(\mathrm{mm})$} & \multirow{2}{*}{$\begin{array}{l}\text { Op Time } \\
\text { (mins) }\end{array}$} & \multirow{2}{*}{$\begin{array}{l}\text { Blood Loss } \\
\quad(\mathrm{ml})\end{array}$} & \multirow[b]{2}{*}{ Complications } & \multirow[b]{2}{*}{ LOS (days) } & \multicolumn{2}{|c|}{ ASIA Classification } \\
\hline & & & & & & & & Preop & Postop \\
\hline \multicolumn{10}{|l|}{ EEO } \\
\hline 1 & $\mathrm{RA}+\mathrm{BI}$ & $42, \mathrm{~F}$ & 12 & 220 & 450 & no & 3 & C & $D$ \\
\hline 2 & $\mathrm{RA}+\mathrm{BI}$ & $52, \mathrm{~F}$ & 9 & 190 & 650 & no & 3 & $\mathrm{C}$ & $D$ \\
\hline 3 & $C M+A A S$ & $28, \mathrm{M}$ & 9 & 200 & 260 & no & 2 & C & $E$ \\
\hline 4 & $\mathrm{RA}+\mathrm{BI}+\mathrm{AAS}$ & $49, F$ & 14 & 300 & 850 & no & 3 & $D$ & $E$ \\
\hline 5 & $\begin{array}{c}\text { AAS + hypoplasia of } \\
\text { basiocciput }\end{array}$ & $42, \mathrm{~F}$ & none & 280 & 650 & no & 3 & C & D \\
\hline \multicolumn{10}{|l|}{ TMO } \\
\hline 1 & AAS & $18, F$ & none & 90 & 60 & no & 6 & C & $\mathrm{D}$ \\
\hline 2 & AAS & $21, \mathrm{~F}$ & none & 120 & 80 & no & 7 & $\mathrm{C}$ & $\mathrm{D}$ \\
\hline 3 & $\mathrm{RA}+\mathrm{AAS}+\mathrm{BI}$ & $42, \mathrm{~F}$ & 6 & 220 & 200 & dysphonia & 7 & C & $E$ \\
\hline 4 & AAS & $16, \mathrm{M}$ & none & 140 & 100 & intraop CSF leak & 10 & $\mathrm{D}$ & $\mathrm{D}$ \\
\hline 5 & AAS & $42, \mathrm{M}$ & none & 120 & 50 & no & 5 & $\mathrm{D}$ & $\mathrm{D}$ \\
\hline 6 & $\mathrm{CM}+\mathrm{AAS}+\mathrm{BI}$ & $29, \mathrm{~F}$ & 6 & 200 & 100 & dysphagia/dysphonia & 6 & C & $\mathrm{D}$ \\
\hline 7 & AAS & $51, \mathrm{~F}$ & none & 100 & 50 & no & 5 & $\mathrm{D}$ & $\mathrm{D}$ \\
\hline
\end{tabular}

* $\mathrm{CM}=$ Chiari malformation; LOS = length of hospital stay; RA = rheumatoid arthritis. 
TABLE 2: Fixation and C-1 anterior arch preservation in 12 patients with odontoidectomy*

\begin{tabular}{clll}
\hline $\begin{array}{c}\text { Case } \\
\text { No. }\end{array}$ & \multicolumn{1}{c}{ Diagnosis } & Fixation & $\begin{array}{c}\text { Preservation } \\
\text { of C-1 }\end{array}$ \\
\hline EEO & & & \\
1 & $\mathrm{RA}+\mathrm{BI}$ & $\mathrm{C} 1-2$ & yes \\
2 & $\mathrm{RA}+\mathrm{BI}$ & $\mathrm{C} 1-2$ & yes \\
3 & $\mathrm{CM}+\mathrm{AAS}$ & $\mathrm{C} 1-2$ & yes \\
4 & $\mathrm{RA}+\mathrm{BI}+\mathrm{AAS}$ & Oc-C2 & no \\
5 & $\mathrm{AAS}+$ hypoplasia of basiocciput & Oc-C2 & no \\
$\mathrm{TMO}$ & & & \\
1 & $\mathrm{AAS}$ & $\mathrm{C} 1-2$ & yes \\
2 & $\mathrm{AAS}$ & $\mathrm{C} 1-2$ & yes \\
3 & $\mathrm{RA}+\mathrm{AAS}+\mathrm{BI}$ & Oc-C2 & no \\
4 & AAS & $\mathrm{C} 1-2$ & yes \\
5 & AAS & C1-2 & yes \\
6 & CM $+\mathrm{AAS}+\mathrm{BI}$ & Oc-C2 & no \\
7 & AAS & Oc-C2 & no \\
\hline
\end{tabular}

* Oc = occiput.

In our series we had $1 \mathrm{CSF}$ leak in the TMO group that was repaired with fat graft and fibrin glue. There have not been persistent CSF leaks or late infectious complications reported in the literature with the EEO. ${ }^{15}$ The EEA provides a shorter route to the surgical field ${ }^{2}$ and the closeup view allows better drilling precision, which in our opinion prevents dural tears. In previous reports only 3 cases of velopharyngeal insufficiency (VPI) ${ }^{3,25}$ have been detailed, which resolved during the follow-up, and there was 1 death attributed to pulmonary embolism 2 weeks after surgery. ${ }^{25}$ In our series, we did not document VPI and there were no deaths.

Basilar invagination favors complete EEA resection of the odontoid process; however, it is essential in the preoperative analysis to project the nasopalatine line in the CT. De Almeida et al. ${ }^{7}$ demonstrated that the nasopalatine line infers accurately the most inferior limit of endoscopic endonasal dissection $(8.9 \mathrm{~mm}$ above the base of the $\mathrm{C}-2$ vertebral body). We could achieve complete odontoidectomy in the 12 cases, and the trajectory using the nasopalatine line was accurate for the EEA group. Nevertheless, accurate neuronavigation is an important adjunct for achieving a complete odontoidectomy. Hickman et al. ${ }^{12}$ reported a pediatric endonasal odontoidectomy that required a second intervention, and they explained that the main factor was the lack of accuracy of the navigation system because of the loosening of the head pins in the thin skull attributable to osteogenesis imperfecta. Gempt et al. ${ }^{9}$ performed a second surgery for a laterally and caudally expanded resection 5 days after the first surgery, due to persistent symptoms and brainstem compression. They agreed with the importance of neuronavigation because there are no clear landmarks for the lateral extent of the resection; however, the lateral exposure is limited by the eustachian tubes initially and by the atlantooccipital articulation deep in the field.
Partial anterior $\mathrm{C}-1$ ring preservation may provide better occipitocervical stability. ${ }^{2,24}$ The preservation of the anterior arch of $\mathrm{C}-1$ provides support in the coronal plane and acts as a physiological cross-link limiting lateral displacement for the lateral masses of C-1 caused by the wedging of $\mathrm{C}-1$ between the occiput and C-2.13,24 When feasible, odontoidectomy with preservation of the anterior arch of the atlas was done (Table 2), so in conjunction with C1-2 arthrodesis, odontoidectomy stabilizes the occipital-atlantoaxial segments while conserving more cervical mobility compared with an occipital-cervical fusion. ${ }^{27}$ Wright $^{33}$ described the C-2 translaminar screw fixation connected to $\mathrm{C}-1$ lateral mass screws, offering rigid fixation without the technical difficulties of C-2 pars instrumentation and eliminating the risk of vascular injury (vertebral artery). In our cases, C1-2 arthrodesis was performed using C-1 lateral mass and C-2 translaminar screws, which is easier, safer, and faster than other techniques, with good biomechanical results..$^{4,28}$

Arguably, because of the learning curve of the surgery, time and blood loss were higher with EEA. We hypothesize that acquiring more experience with the expanded EEA could significantly reduce the surgical time. The higher estimated blood loss in EEA could be attributable to the longer drilling time as well as to the availability of fibrin sealants, which is dependent on the economic status of the patient. The time to extubation and feeding was significantly shorter for the EEA group, confirming the data reported by Komotar et al. ${ }^{15}$ in their study, shortening the hospital stay in comparison with the TMO group, which considerably reduces the hospital costs for the patient. The clinical outcome is related to the chronicity of the myelopathy and the severity of the preoperative neurological deficit. Clinical improvement was similar for both approaches because both provide adequate brainstem or spinal cord decompression; however, it seems that complications might be reduced with the EEA.

Other alternatives had been reported to improve some of the disadvantages of the TMA. Using the endoscope in the transoral approach prevents splitting of the soft palate ${ }^{8}$ however, compression of the tongue, airway swelling, VPI, and damage to the mouth and teeth are not prevented. Robot-assisted transoral odontoidectomy may decrease the tongue retraction, lessen damage to the mouth and teeth, improve safety, and avoid difficulties during the pharyngeal dissection, and, in the case of CSF leakage, reapproximation of the dura could be done successfully with the da Vinci Surgical System. ${ }^{35}$ On the other hand, the endoscopic transcervical route ${ }^{32}$ provides a sterile surgical field and fewer retraction complications, but is limited to CVJ pathological entities beneath the lower clivus. ${ }^{2}$ However, anatomically the EEA has better advantages than the transoral endoscopic, robot-assisted, and transcervical approaches in lesions above the nasopalatine line. The use of the da Vinci Surgical System looks promising once the proper instrumentation has been developed for endoscopic endonasal techniques.

Even though there is a selection bias based on the anatomy of the lesion (position of the dens in relation to the nasopalatine line), our initial experience favors the endoscopic endonasal route for the following reasons: a 


\section{J. A. Ponce-Gómez et al.}

better view, safer drilling, less bacterial contamination, no tongue or airway swelling, no need of a nasogastric tube, no complications, shorter time to extubation and oral feeding, and a shorter hospital stay. Although EEO has already proved to be safe, effective, and with lower morbidity than the transoral route, ${ }^{15}$ experience with EEA from other centers is necessary for evaluating the effectiveness of this approach further.

\section{Conclusions}

Previous studies ${ }^{3,9-12,14,16,17,22,25,26,30,31,34}$ have demonstrated the effectiveness and feasibility of an odontoidectomy performed using an EEA and suggest the possibility of less invasiveness than with the oral or cervical approaches. In our small series there is no evidence of different neurological functional outcomes between the techniques. There is a reduction in the complication rates related to the surgical route that favors EEA.

\section{Acknowledgments}

We are indebted to our professional neuroanesthesiology department and our great neurosurgical nursing team.

\section{Disclosure}

The authors report no conflict of interest concerning the materials or methods used in this study or the findings specified in this paper.

Author contributions to the study and manuscript preparation include the following. Conception and design: Barges-Coll, Ponce-Gómez, Ortega-Porcayo, Gómez-Amador. Acquisition of data: Barges-Coll, Ponce-Gómez, Ortega-Porcayo. Analysis and interpretation of data: all authors. Drafting the article: Barges-Coll, Ponce-Gómez, Ortega-Porcayo, Soriano-Barón. Critically revising the article: all authors. Reviewed submitted version of manuscript: all authors. Approved the final version of the manuscript on behalf of all authors: Barges-Coll. Statistical analysis: Ponce-Gómez, Ortega-Porcayo. Administrative/technical/material support: BargesColl, Ponce-Gómez, Ortega-Porcayo, Soriano-Barón, SotomayorGonzález, Arriada-Mendicoa, Gómez-Amador. Study supervision: Barges-Coll, Ponce-Gómez, Ortega-Porcayo, Arriada-Mendicoa, Gómez-Amador, Palma-Díaz.

\section{References}

1. Alfieri A, Jho HD, Tschabitscher M: Endoscopic endonasal approach to the ventral cranio-cervical junction: anatomical study. Acta Neurochir (Wien) 144:219-225, 2002

2. Baird CJ, Conway JE, Sciubba DM, Prevedello DM, Quiñones-Hinojosa A, Kassam AB: Radiographic and anatomic basis of endoscopic anterior craniocervical decompression: a comparison of endonasal, transoral, and transcervical approaches. Neurosurgery 65 (6 Suppl):158-164, 2009

3. Beech TJ, McDermott AL, Kay AD, Ahmed SK: Endoscopic endonasal resection of the odontoid peg-case report and literature review. Childs Nerv Syst 28:1795-1799, 2012

4. Claybrooks R, Kayanja M, Milks R, Benzel E: Atlantoaxial fusion: a biomechanical analysis of two C1-C2 fusion techniques. Spine J 7:682-688, 2007

5. Crockard HA: Transoral surgery: some lessons learned. Br J Neurosurg 9:283-293, 1995

6. Crockard HA, Pozo JL, Ransford AO, Stevens JM, Kendall BE, Essigman WK: Transoral decompression and posterior fusion for rheumatoid atlanto-axial subluxation. J Bone Joint Surg Br 68:350-356, 1986
7. de Almeida JR, Zanation AM, Snyderman CH, Carrau RL, Prevedello DM, Gardner PA, et al: Defining the nasopalatine line: the limit for endonasal surgery of the spine. Laryngoscope 119:239-244, 2009

8. Frempong-Boadu AK, Faunce WA, Fessler RG: Endoscopically assisted transoral-transpharyngeal approach to the craniovertebral junction. Neurosurgery 51 (5 Suppl):S60-S66, 2002

9. Gempt J, Lehmberg J, Grams AE, Berends L, Meyer B, Stoffel M: Endoscopic transnasal resection of the odontoid: case series and clinical course. Eur Spine J 20:661-666, 2011

10. Hankinson TC, Grunstein E, Gardner P, Spinks TJ, Anderson $\mathrm{RC}$ : Transnasal odontoid resection followed by posterior decompression and occipitocervical fusion in children with Chiari malformation Type I and ventral brainstem compression. Report of 2 cases. J Neurosurg Pediatr 5:549-553, 2010

11. Hansen MA, da Cruz MJ, Owler BK: Endoscopic transnasal decompression for management of basilar invagination in osteogenesis imperfecta. Technical note. J Neurosurg Spine 9: 354-357, 2008

12. Hickman ZL, McDowell MM, Barton SM, Sussman ES, Grunstein E, Anderson RC: Transnasal endoscopic approach to the pediatric craniovertebral junction and rostral cervical spine: case series and literature review. Neurosurg Focus 35(2):E14, 2013

13. Hwang SW, Heilman CB, Riesenburger RI, Kryzanski J: C1$\mathrm{C} 2$ arthrodesis after transoral odontoidectomy and suboccipital craniectomy for ventral brain stem compression in Chiari I patients. Eur Spine J 17:1211-1217, 2008

14. Kassam AB, Snyderman C, Gardner P, Carrau R, Spiro R: The expanded endonasal approach: a fully endoscopic transnasal approach and resection of the odontoid process: technical case report. Neurosurgery 57 (1 Suppl):E213, 2005

15. Komotar RJ, Starke RM, Raper D, Anand VK, Schwartz TH: Endonasal endoscopic versus transoral microscopic odontoid resection. Innovative Neurosurg 1:37-47, 2013

16. Laufer I, Greenfield JP, Anand VK, Härtl R, Schwartz TH: Endonasal endoscopic resection of the odontoid process in a nonachondroplastic dwarf with juvenile rheumatoid arthritis: feasibility of the approach and utility of the intraoperative Iso-C three-dimensional navigation. Case report. J Neurosurg Spine 8:376-380, 2008

17. Leng LZ, Anand VK, Hartl R, Schwartz TH: Endonasal endoscopic resection of an os odontoideum to decompress the cervicomedullary junction: a minimal access surgical technique. Spine (Phila Pa 1976) 34:E139-E143, 2009

18. Magrini S, Pasquini E, Mazzatenta D, Mascari C, Galassi E, Frank G: Endoscopic endonasal odontoidectomy in a patient affected by Down syndrome: technical case report. Neurosurgery 63:E373-E374, 2008

19. Menezes AH, VanGilder JC: Transoral-transpharyngeal approach to the anterior craniocervical junction. Ten-year experience with 72 patients. J Neurosurg 69:895-903, 1988

20. Menezes AH, VanGilder JC, Clark CR, el-Khoury G: Odontoid upward migration in rheumatoid arthritis. An analysis of 45 patients with "cranial settling." J Neurosurg 63:500-509, 1985

21. Menezes AH, VanGilder JC, Graf CJ, McDonnell DE: Craniocervical abnormalities. A comprehensive surgical approach. J Neurosurg 53:444-455, 1980

22. Messina A, Bruno MC, Decq P, Coste A, Cavallo LM, de Divittis E, et al: Pure endoscopic endonasal odontoidectomy: anatomical study. Neurosurg Rev 30:189-194, 2007

23. Mummaneni PV, Haid RW: Transoral odontoidectomy. Neurosurgery 56:1045-1050, 2005

24. Naderi S, Crawford NR, Melton MS, Sonntag VKH, Dickman CA: Biomechanical analysis of cranial settling after transoral odontoidectomy. Neurosurg Focus 6(6):E7, 1999

25. Nayak JV, Gardner PA, Vescan AD, Carrau RL, Kassam AB, Snyderman $\mathrm{CH}$ : Experience with the expanded endonasal ap- 


\section{From transoral to endonasal odontoidectomy}

proach for resection of the odontoid process in rheumatoid disease. Am J Rhinol 21:601-606, 2007

26. Patel AJ, Boatey J, Muns J, Bollo RJ, Whitehead WE, Giannoni CM, et al: Endoscopic endonasal odontoidectomy in a child with chronic type 3 atlantoaxial rotatory fixation: case report and literature review. Childs Nerv Syst 28:1971-1975, 2012

27. Puttlitz CM, Melcher RP, Kleinstueck FS, Harms J, Bradford DS, Lotz JC: Stability analysis of craniovertebral junction fixation techniques. J Bone Joint Surg Am 86-A:561-568, 2004

28. Savage JW, Limthongkul W, Park HS, Zhang LQ, Karaikovic EE: A comparison of biomechanical stability and pullout strength of two C1-C2 fixation constructs. Spine J 11:654658,2011

29. Seker A, Inoue K, Osawa S, Akakin A, Kilic T, Rhoton AL Jr: Comparison of endoscopic transnasal and transoral approaches to the craniovertebral junction. World Neurosurg 74:583-602, 2010

30. Sinha S, Mirza S, Bishop N, Zaki H, McMullan J: Endoscopic endonasal resection of the odontoid peg for paediatric basilar invagination. Br J Neurosurg 26:487-489, 2012

31. Tomazic PV, Stammberger H, Mokry M, Gerstenberger C, Habermann W: Endoscopic resection of odontoid process in Arnold Chiari malformation type II. B-ENT 7:209-213, 2011

32. Wolinsky JP, Sciubba DM, Suk I, Gokaslan ZL: Endoscopic image-guided odontoidectomy for decompression of basilar invagination via a standard anterior cervical approach. Technical note. J Neurosurg Spine 6:184-191, 2007

33. Wright NM: Posterior C2 fixation using bilateral, crossing $\mathrm{C} 2$ laminar screws: case series and technical note. J Spinal Disord Tech 17:158-162, 2004

34. Wu JC, Huang WC, Cheng H, Liang ML, Ho CY, Wong TT, et al: Endoscopic transnasal transclival odontoidectomy: a new approach to decompression: technical case report. Neurosurgery 63 (1 Suppl 1):ONSE92-ONSE94, 2008
35. Yang MS, Yoon TH, Yoon DH, Kim KN, Pennant W, Ha Y: Robot-assisted transoral odontoidectomy: experiment in new minimally invasive technology, a cadaveric study. J Korean Neurosurg Soc 49:248-251, 2011

36. Yu Y, Hu F, Zhang X, Ge J, Sun C: Endoscopic transnasal odontoidectomy combined with posterior reduction to treat basilar invagination. Technical note. J Neurosurg Spine 19: 637-643, 2013

Manuscript submitted June 12, 2014.

Accepted July 11, 2014.

Please include this information when citing this paper: DOI: 10.3171/2014.7.FOCUS14301.

Supplemental online information:

Video 1: http://mfile.akamai.com/21490/wmv/digitalwbc.download. akamai.com/21492/wm.digitalsource-na-regional/focus14-301_ video_1.asx (Media Player).

http://mfile.akamai.com/21488/mov/digitalwbc.download.akamai. com/21492/qt.digitalsource-global/focus14-301_video_1.mov (Quicktime).

Video 2: http://mfile.akamai.com/21490/wmv/digitalwbc.download. akamai.com/21492/wm.digitalsource-na-regional/focus14-301_ video_2.asx (Media Player).

http://mfile.akamai.com/21488/mov/digitalwbc.download.akamai. com/21492/qt.digitalsource-global/focus14-301_video_2.mov (Quicktime).

Address correspondence to: Juan Barges-Coll, M.D., M.Sc., Division of Neurological Surgery, National Institute of Neurology and Neurosurgery "Manuel Velasco Suarez," 3877 Insurgentes Sur. La Fama, Tlalpan, Mexico City 14269, Mexico. email: jbargescoll@ mac.com. 